\title{
If It Dries Out, It's No Good: Women, Hair and Rusalki Beliefs
}

\author{
Philippa Rappoport, University of Virginia
}

\section{INTRODUCTION}

There is something instinctual about communicating social behavior and intentions through hair. I have spent summers in Russia with my hair pulled back demurely, trying to remain inconspicuous, the observer rather than the observed. I noticed how, almost uniformly, little girls wear hair ribbons which are bigger than their heads; how mod young women in mini skirts wear their hair loose; how relatively reserved women pull their hair back; how the older ones keep their heads covered in kerchiefs. In his article "Magical Hair" (1957), Edmund Leach discusses hair as a prominent feature of rites of passage across cultures. He writes:

From [an] anthropological point of view, [rites of passage] reflect the progression of the individual through set stages in the social system; these stages correspond to different degrees of maturity, different types of permitted sexual behavior, different allocations of social power...Even the most skeptical anthropologist must admit that head hair is rather frequently employed as a public symbol with an explicitly sexual significance ...Marked changes in hairdressing very commonly accompany the changes in sexual status that occur at puberty and marriage, but the pattern of change varies.(1)

In Russia today, age and sexuality are expressed through hair, but the type of expression has changed, reflecting changes in society and worldview.(2) This paper examines earlier manifestations of East Slavic beliefs about hair and sexuality as expressed in the traditional wedding ritual complex and in customs related to the rusalka. In the wedding ritual, the bride is "sold" to her new husband and his family, and must leave her home and village. As part of the ritual, she "sells" her braid to her new husband, and is valued for the thickness of her braid. I will argue that this act is symbolic of a woman's giving over her sexual potency and autonomy to her husband and to her new marriage. In addition to discussing the role of hair in ritual, I will suggest an interpretation of the wedding as a sort of a blueprint of the history of the wedding ritual itself. The ritual itself, in my opinion, reflects a transition in the role of women in a society increasingly influenced by the Orthodox Church.

\section{THE RITUALS}

As with all folklore, beliefs are articulated in a variety of ways. Traditionally, young girls and women were distinguished from each other by dress; they were also distinguished by hair and headgear. Customs and rituals involving hair portray a system of social position. A young girl wore her hair either loose or in one braid on the back of her head. The single braid may have been adomed 
with ribbons, flowers, beads, or feathers. A girl's headdress did not completely cover her hair, and was open on top. Married women, on the other hand, wore their hair in two braids which were hidden in a headdress. Their headdress was covered with a white or red kerchief, decorated with embroideries of birds and animals. In her article "The Woman in the Ancient Russian Family (Tenth to Fifteenth Centuries), "Natal'ia Pushkareva describes eleventh and twelfth century practices which permitted married women to show their hair only to their husbands, or which prohibited people from removing a woman's headdress, on penalty of a large fine, because such an act was considered an affront to a woman's honor. By the nineteenth and early twentieth centuries, married women were supposed to keep their hair covered because uncovered hair was believed to bring unhappiness.(3)

In his book about the folk costume of Moravian Slovakia, Petr Bogatyrev discusses women's headgear. He maintains that the maiden-costume of some Moravian-Slovak communities functioned not only to show the age and status of a woman, but her sexual morality as well. He states that when an unmarried girl lost her virginity, she was required to wear the married woman's headdress, and in some cases, she suffered the disgrace of having her hair cut off.(4) The link between sexual conduct and hair is also evident in East Slavic customs. As recently as 1998, Natalie Kononenko interviewed a Ukrainian woman who stated that if a woman is not a virgin, she must wear a married woman's headdress.(5)

Pushkareva maintains that the wedding rituals of the tenth through fifteenth centuries show the diminishing domestic and social status of women with the increasing influence of the Church. This diminishing status is articulated in many ways, one of them being rituals related to hair and head apparel. During the wedding ritual complex, hair is treated in two ways. It is controlled, through covering, braiding and concealing. It is also "sold" to the new husband. All of these acts represent a type of submission.

According to some of the major works on the wedding ritual, by folklorists and musicologists such as D.M. Balashov, Iu.I. Marchenko, N.I. Kalmykova, G.S. Maslova, N.V. Zorin, and M. Zabylin, the wedding ritual complex begins with the securing of a match. Once the engagement is agreed upon, the first act done to the bride is the zaporuki, or covering. Other names for this act include zaporuchivat' (to cover lightly), zakryvat' (to cover in the sense of closing or locking) and zaveshivat' nevestu (to cover in the sense of curtaining off the bride). During the zaporuki, the groom, the matchmaker and the father of the bride pray together, light candles before the icon, hold hands and drink tea and wine to seal the agreement. The bride is covered with a kerchief by her father, and she begins to lament.(6) In some areas, the kerchief covers only the bride's head; in other areas, it covers 
her entire body.(7) This act signals the beginning of the wedding period for the bride, and from this moment on, she ceases to be a functioning member of the household. She is relieved of all her household duties, and instead spends her time preparing her dowry. Although customs vary by region, this usually sets off a period in which the bride stays only with her girlfriends, save for an occasional visit by the groom.(8) Thus the covering or concealing of the bride's hair is a symbolic separation of her from her family.

In terms of hair, the next important time of the wedding complex is the final week, or weeks, before the wedding. The bride's hair is repeatedly washed and combed, sometimes greased with honey and butter, and braided (often with kopecks) by her girlfriends or brothers.(9) Again, there is a lot of regional variation. Balashov writes of "the appearance of the bride before the table." He describes this event as the most solemn moment of the ceremony because it is the first time that the bride is shown publicly to the groom. During this encounter, the bride laments the loss of her krasota (beauty), and volia (will), which Balashov describes as symbols of virginity. Often the bride asks for some light, saying she wants her beauty back. In response, someone turns down the head covering, and the bride leaves. She may also throw away her will (volia) in the form of flowers, and then ask for them back, only to despair that it is no longer her fate to wear them.(10) The terms used for items that cover the hair show a direct connection to free will, beauty and sexual potency, as does the attempt to control the potent hair not only by covering it, but also by washing and combing.

One of the more chilling aspects of the braiding is as a means of protection. Ethnographer: I.M. Kolesnitskaia and L.M. Telgina note a sequence in the ritual complex in which the bride requests that her friends unbraid and replait her hair, weaving the ribbons in tightly, so that her new mother-inlaw will neves be able to undo the braid. This motif appears often in wedding laments from northern Russia, with the image of metal knives or locks, which the friends must plait into the hair, to lock the braid. This imagery suggest that the braid is directly symbolic of the girl's sexual organs, which she requests to be locked up, to protect her from the groom and his family. (11)

The bride's hair is also washed and rebraided during the devishnik, or bachelorette party, which occurs on the night before the wedding, and it may be braided on the morning of the wedding itself. This grooming often occurs while the bride is washing herself in the bathhouse (for the first time since the engagement), and is accompanied by more lamenting over the loss of her beauty. According to one description, the bride tells her girlfriends that she has hidden her beauty in inaccessible places such as the stove under the threshold, but that if they can find it, they can have it. She then gives them her hair ribbons. There is a sense in these rituals that the bride is bequeathing her 
premarital will to her girlfriends through her hair ribbons, and also through her bath water. The girlfriends drink the water in which the bride has bathed, perhaps as a magical act, so that they, too, will marry.(12)

The next part of the ceremony is extremely interesting for the way in which hair used to articulate power and danger. The whole wedding party goes to the church. This segment is considered to be a dangerous time, because the bride is believed to be the most susceptible to sorcery - or perhaps it is those around her who are susceptible. Significantly, her hair is loose, and she is covered with the pokryvalo, a cloth which covers the bride's head and sometimes her whole body.(13) According to Balashov, Marchenko and Kalmykova, the groom places this covering on the bride and puts her in the cart to take her to the church. Presumably this is done in the belief that if the bride does not leave of her own power this time, she will be unable to leave on her own in the future.(14) Again, there are regional variations on this theme. Maslova writes that the bride's covering is removed in church by a member of the groom's family or party, and she is then covered again with a shawl or bridal veil. Maslova emphasizes that uncovering the bride and significantly her hair somewhere other than in the church was dangerous and could invite spoiling or sorcery. Zabylin writes that in Perm, the matchmaker leads the bride and groom to a corner of the church where she places the married woman's headdress on the bride's head and rebraids her hair. When they leave the church and arrive back at the house, the matchmaker leads the newlyweds away from the rest of the guests and rebraids the bride's hair into two braids - the signal that she is now a married woman - and places the proper headdress on her. Then everyone is called to the table for the meal. In some areas of Ukraine, the bride's hair is done in two braids before the groom arrives in the morning.(15) One of the culminating events of the wedding is the okruchivanie (winding up, or wrapping around). Having said a ritual farewell to her braid, the bride now has her hair braided in two and wrapped up under the headdress.(16)

The one time when the hair is not controlled is during the trip to church. Pushkareva notes a distinction between the folk part of the ceremony and the church part, stating that the popular ritual was considered indispensable to the validity of the marriage, while the church ceremony was not essential.(17) It is crucial that, at the juncture between the folk and the church segments of the ceremony, the bride's hair is loose. This ritualized journey to the church, considered to be the most "dangerous" sequence in the entire ceremony, may represent and document a transition in ritual and in history from pre-Christian to Christian influence. The loose hair of the bride at this point may be a remnant of a former, pre-monogamous society and symbolic of the bride's sexual fertility, and of her 
freedom, which she is about to relinquish upon partaking in the church service. Pushkareva also states that the emphasis on virginity is a Church influence rather than a folk custom.(18) Is it possible that the ceremonial switching of the crowns that is typical of the Orthodox Church wedding represents a reversal of the power structure between a woman and a man? It is probably no coincidence that the bride, who is valued for her reproductive ability, is considered to be sold to her husband under the symbolism of selling her braid. Maslova notes a belief that the symbolic sale of the braid to the new husband is an indication that he is the master and the bride is his slave.(19) This symbolism is only barely hidden in the wedding ritual complex. Is this why the bride laments?

\section{THE RUSALKA}

In contrast to the bride, there is a female folk figure in traditional East Slavic lore whose hair is permanently loose and uncontrolled; she is the rusalka. The rusalka of traditional beliefs is a powerful and enticing figure. She is described as a pale, lithe, often beautiful female spirit who lives in the water, forests and fields. She sits with other water spirits on the shore, yelling and laughing, or dancing and singing in the moonlight of clear, summer nights. She is known to swing on tree branches, waiting to entice an unsuspecting male passer-by, whom she often attacks and (perhaps inadvertently) tickles to death. The rusalka's characteristic physical attributes are her long, light-brown, blond, or green, loose hair, her blazing eyes, and her magnificent breasts. She is noted for her beautiful voice and melodious laugh. On the rare occasions when the rusalka is dressed, she wears white. In addition, some sources report that if the rusalka, and especially her hair, ever dries out, she will perish.(20)

The risalka was believed by many nineteenth century peasants to be the soul of an unbaptized or stillborn baby, or the wandering soul of a young, unmarried but often betrothed woman who had died an untimely death, or who had become pregnant out of wedlock and drowned or hanged herself. In this way, she may be seen as a symbol of potent yet not-quite-tapped fertility, and as such is celebrated and feared during the spring festival, Rusal'naia nedelia (mermaid week), during which people played music, danced and sang to celebrate new vegetation. It was during this week that the rusalka was believed to leave her watery home to wander in the forests and fields, and bring moisture to the crops. Peasants decorated their homes with fresh green birch branches (the rusalka's tree), and young girls often went to the woods and decorated actual trees with cloth, thread and garlands, and then danced the khorovod (circle dance) and swore vows of friendship and sisterhood. But the water creature was also feared at this time. To appease her, peasant women left offerings in the woods of scarves and linen. Others attempted to minimize the rusalka's harm by using the sign of the cross, magic circles, garlic, wormwood, incense, pokers and charms.(21) 
At the end of Rusal'naia nedelia, village girls escorted an effigy of the rusalka out of the village and back towards her forest or water home. In some areas they burned or tore up and distributed pieces of the dummy in the grain field. In other areas, they pretended to be priests and blessed the dummy. In still other areas, they combed her hair, bid farewell to her at the local body of water, fastened stones to her coffin, threw her into the water, and danced the circle dance. Interpretations of these rituals acknowledge both the frightening aspects of the rusalka in the need to banish her, as well as her moist, life-giving attributes and the attempt to renew the cycle of fertility and vegetation.(22)

The rusalka is considered by some to be a remnant of goddess worship. In some Ukrainian sources, she is called bohynia (goddess).(23) Accordingly, she is a powerful, yet playful, female figure who can be tamed by a cross, baptism and marriage. At this point, she makes a lovely wife. Otherwise, apparently out of loneliness, she tries to bring men to her home to live, which for a human man, implies drowning.(24) The rusalka's description shows very handily the inversion which occurs to an important pre-Christian figure with the growing influence of Christianity. What was once sacred becomes profane; what was positive becomes negative. The rusalka is probably a descendant of Mokosh', the goddess of fertility, bounty and moisture, and the protectress of women's work and the fate of maidens.(25) Her taming by the cross may reflect just that - the taming of belief in the rusalka as a powerful supernatural figure due to the influence of Christianity, which did not acknowledge the pagan gods and goddesses.

It is possible that the rusalka is a remnant of an older society in which women were freer to express their sexuality. Many Slavic sources state that, with the influence of nomadic patriarchal tribes and, later, of Christianity, Slavic cultures became increasingly more patriarchal and monogamous marriage was instituted. The influence of the church may have served to break the identity of village girls with the rusalka, and instead, to make them enemies who compete for the same village men. It may also have served to criticize the uninhibited sexuality and sensuality which the rusalka continually expresses. One of the rituals associated with Rusal'naia nedelia is actually a mock remnant of the wedding ritual. Propp writes that in some areas, when the girls return from the fields, they make bonfires and jump over them. Boys approach the girls and the girls try to throw their crowns on them, while the girls mimic the rusalka, trying to catch the boys and tickle them.(26) In light of the crowning sequence in the church ceremony, these games almost certainly pair the future bride with the rusalka.(27) Additionally, the constant washing of the bride's hair is also reminiscent of the rusalka's hair, which must always be moist. 
In her article "Women as Performers of Oral Literature: A Reexamination of Epic and Lament," Natalie Kononenko enumerates the similarities between the wedding ceremony and the funeral. She writes about the rusalka:

It is tempting to see the rusalka as a remnant of a pre-Christian deity, forced underground, or, more literally, underwater by a new religion. It is also tempting to see the rusalka's life as a reflection of an early social order where there was no marriage and women accepted men into their domain to father children. Speculation aside, folk belief articulates clearly that a woman who resists marriage, especially one who gets pregnant outside marriage is bad. A woman who does not submit to the symbolic death of the wedding must accept the literal death of the rusalka. A woman who does not become spiritual as a married woman should, must become a spirit and a bad one at that.(28)

In this light, marriage may be seen as an institution through which both human women and rusalkas lose their freedom. Human women are sold to their new husbands through the symbolism of their hair which is then hidden from everyone except the husband; rusalkas, beings with unbound hair and the souls of dead women, are in a sense brought back to an acceptable life only when overpowered by the institutions of the Church - a cross, baptism and marriage.

This connection between the rusalka, a lovely aquiline maiden, who sings in the woods and romps around naked with her hair flowing freely, and the East Slavic bride who sits covered with cloth and sings only dirges, may also be expressed in wedding laments. In one lament, Plach na devishnike, the bride says that she sits in a sad place, with her hair plain, loose and disheveled. She then addresses her beauty (krasota) and releases it to the fields, meadows, forests and rivers.(29) In another lament, Plach nevesty v den'svad'by, the bride releases her will (volia), and it flies to the woods and alights on a fir tree. When she tries to retrieve it, someone has chopped down the tree, in a Freudian deflowering.(30) It may be that these images are references to the attributes of the rusalka, such as beauty and free will, which the unmarried girl possesses but then relinquishes in marriage.

This loss of freedom exists on two levels: On one level, it is a loss of freedom that any new spouse undertakes in pledging fidelity to one person. On another level, in conjunction with the patriarchal bent of the church and the wedding ritual complex, it is specifically the bride's yielding of her own will to her dominant husband. This image is recalled in Maslova's discussion of the ritual "selling of the braid," which she interprets as a symbol of the bride's submission to her husband.(31) CONCLUSION

Pushkareva notes a transition in the wedding ceremony from the tenth to the fifteenth centuries. Specifically, she describes the earlier wedding ceremony as one which was based on a contract which had been agreed upon by both bride and groom. By the sixteenth century, though, due 
to "subjugation by the Golden Horde,... strengthening of a despotic political system... [and] the growing influence of an ascetic Christian doctrine, "women in the higher classes lost their personal, proprietary and hereditary rights.(32)

This sense of historical transition from non-patriarchal to patriarchal influence is reflected in the actual traditional wedding ritual itself, and in specific rituals dealing with hair. The tidying of the hair for the wedding may be an implicit attempt to order, own, or contain the chaotic freedom associated with the woman and her sexual energy and expressed in the rusalka. In addition to making order out of a type of chaos, the constant washing, combing and plaiting of the bride's hair may be an attempt to conjure up the fertility of the rusalka, much like the grooming of a garden, so that the bride may bring this potent productivity to her marriage.(32)

In any event, hair is indeed a potent means of sexual expression, whose roots go deep in Russia, Ukraine and Belarus. Even after the disintegration of the traditional wedding ritual, hair is still used to express social and sexual behavior. Nadezhda Azhgikhina and Helena Goscilo describe a series of contests organized in Moscow in the 1990s - for Miss Bust, Miss Legs, Miss Erotic, and Miss Hair. The contestants in the 1994 competition for Miss Hair wore only bikini briefs and loose hair.(33) They may not have consciously conjured up the image of the rusalka, but surely the rusalka was laughing stage left.

Notes

1. Edmund Leach, "Magical Hair," Myth and Cosmos, ed. John Middleton (New York: Natural History Press, 1967) 103, 89.

2. For a discussion of contemporary sexual expression through hair, see Nadezhda Azhgikina and Helena Goscilo's article "Getting Under Their Skin:The Beauty Salon in Russian Women's Lives" and other articles in Part I of Russia Women. Culture, Ed. Helena Goscilo and Beth Holmgren (Bloomington, Indianapolis: Indiana University Press, 1996).

3. N.L. Pushkareva, "The Woman in the Ancient Russian Family, "Russian Traditional Culture: Religion, Gender, and Customary Law, ed. Marjorie Mandelstam Balzer (New York and London: M.E. Sharpe, 1992)

111. Also in S.P. Shkol'nikov, Pricheski. golovnve ubory i ukrasheniia dlia stseni (Minsk: Vysheishaiia shkola, 1975) 73-78, and G.S. Maslova, Narodnaia odezhda v vostochnoslavianskikh traditsionnvkh obvchoiakh I obriadakh XLX-nachala XX v. (Moscow: Nauka, 1984) 50-54. See also Women in Russian History, Natalia Pushkareva (New York and England: ME Sharpe, 1997) for descriptions of hair, headdresses and other clothing of the aristocracy, 179-185.

4. Petr Bogatyrev, The Functions of Folk Costume in Moravian Slovakia (The Hague: Mouton, 1971) 73-74.

5. Odarka Iakivna Pan'ko, s.Domantovo, Zolotoniskyi r-n, Cherkas'ka obl., collected by Natalie Kononenko, 8-13-98. According to Odarka Pan'ko, women who bore children out of wedlock were called pokrytky and had to wear the headdress of married women. 
6. D.M. Balashov, Iu.I. Marchenko, N.I. Kalmykova, Russkaia svad'ba: Svadebmvi obriad na Verkhnei i Srednei Kokshen'ge i na Ufiuge (Moscow: Sovremennik, 1985) 33-34.

7. Maslova, 54-55.

8. Balashov, 33-34, Maslova, 8-11, and N.V. Zorin, Russkaia svad'ba v Srednem Povolzh'e (Kazan: Kazanskii universitet, 1981) 87-89.

9. Maslova, 47-50.

10. Balashov, 131-137.

11. I.M. Kolesnitskaia and L.M. Telgina, "Kosa i krasota v svadebnom fol 'klore vostochnykh slavian," Fol 'klor i etnografiia, ed. B.N. Putilov (Leningrad: Nauka, 1977) 113-114.

12. Zorin, 98-101, Balashov, 131-132, 207-209.

13. M. Zabylin, Russkii narod: ego obvchai. obriady predaniia sueveriia i poeziia. (1880; reprint, St. Petersburg: Brait lait, 1994) 289-292, and Maslova, 54-55.

14. Balashov, 131-132.

15. Zabylin, 120-121, 128-134.

16. Maslova, 55-60.

17. Pushkareva, Women in Russian History, 94.

18. Pushkareva, Women in Russian History, 33.

19. Maslova, 47-49.

20. E.V. Pomerantseva, Mifologicheskie personazhi v russkom fol'klore (Moscow: Nauka, 1975)

68-74, Linda Ivanits, Russian Folk Belief (New York and London: ME Sharpe, 1989) 75-76, Natalie (Moyle) Kononenko, "Mermaids (Rusalki) and Russian Beliefs about Women", New Studies in Russian Language and Literature. (Columbus, Ohio: 1987) 221-223.

21. Ivanits, 75-79, Pomerantseva, 72-79, Kononenko, "Mermaids," 224, and A.N. Afanas'ev, Poeticheskiia vozzreniia slavian" na prirodu vol. III (1869; reprint The Hague, Paris: Mouton, 1970) 240.

22. D.K. Zelenin, Ocherki russkoi mifologii: Umershie neestestvennoiu smert'iu i musalki (1916; reprint, Moscow: Indrik, 1995) 264 and Vladimir Propp, Russkie agrarnue prazdniki (1963; reprint, Saint Petersburg: Azbuka, 1995) 88, 90-92, Ivanits, 80-81.

23. Volodomyr Hnatiuk, Etnografichnvi zbyrnik t.2, vyp.2, "Znadoby do ukraïns 'koii demonolohii," (L'viv: Naukove tovarystvo imeny Shevchenka, 1912), 191-198.

24. Ivanits, 75-76, Kononenko, 225.

25. Ivanits, 16.

26. Propp, 90.

27. These games may even be viewed as plays for dominance: the girls try to win the boys by tickling them, as the pre-Christian rusalka would, while the boys try to catch the girls according to the rituals of the church.

28. Natalie Kononenko, "Women as Performers of Oral Literature: A Reexamination of Epic and Lament.", Women Writers in Russian Literature, ed. Toby W. Clyman and Diana Greene (Westport, Connecticut and London, England: Greenwood Press, 1994) 23.

29. K.V. Chistov, Ed. Prichitaniia. Biblioteka poeta series. (Leningrad: Sovetskii pisatel', 1960) 366-368, 417.

30. Chistov, 368-371, 417.

31. Maslova, 47-49.

32. Pushkareva, "Family" in Balzer, 105.

33. These grooming lines recall for me lines on clay figurines from the East Slavic areas, dating back to $6500-3500 \mathrm{BC}$. The figurines are generally considered to be female talismans, or fertility cult objects. Perhaps the combing lines in the hair and the incised lines on the figurines may be likened in some distant way to the gardener's grooming lines in Mat'syra zemlia (Mother Moist Earth), another 
numen, in addition to the rusalka, associated with dampness and fertility. In The Goddesses and Gods of Old Europe: Myths and Cult Images (1974; reprint, Berkeley, Los Angeles, New York: University of California Press, 1992) Marija Gimbutas writes that parallel lines symbolize streams and mythical creatures considered to be the source of water (112-151). Perhaps they are very distant relatives of the rusalka, the East Slavic goddess who bring moisture to the fields.

34. Azhgikina and Goscilo, "Getting Under Their Skin," 113-115. 